\title{
DINAMIKA PENDIDIKAN DASAR MUHAMMADIYAH DI SD MUHAMMADIYAH 05 KEPAHIANG
}

\author{
Lety Febriana \\ Dosen PAI Universitas Muhammadiyah Bengkulu \\ Tari Oktaviana, \\ Dosen Universitas Muhammadiyah Bengkulu \\ Surohim \\ Dosen Universitas Muhammadiyah Bengkulu
}

\begin{abstract}
Muhammadiyah organizations began to enter Kepahiang 1926. In Kepahiang, Muhammadiyah organization has several charities in the field of education, started from Primary Education to Secondary Education. One of them is Muhammadiyah Primary Schools. Muhammadiyah in Kepahiang has five primary schools that already exist when the Dutch were still colonizing in Kepahiang, and it can be said that Muhammadiyah primary education had existed before Indonesian Independence. The method used in this research is the Historical approach method. In this case it is used to answer questions $(5 \mathrm{~W}+1 \mathrm{H})$. As for Heuristics which are used by observation and interviews, then the data obtained is verified so that it gets valid data. Based on the data that have been verified from various sources, both oral and written, it was found that Muhammadiyah Primary Schools began to be established since 1926, the first school to be established was Muhammadiyah People's School. In its growth, Muhammadiyah education began to experience a decline in its existence during the New Order era, because at that time the President's instruction was to uphold private schools so that many new State schools emerged. Seeing the condition, Muhammadiyah officials in the district of Kepahiang thought hard to increase the existence of the Muhammadiyah School again, one of the which was done at the Muhammadiyah Kepahiang People's School which has changed its name several times, from People's School (SR) Muhammadiyah to Elementary School 05 Muhammadiyah Kepahiang, to the latest now become IT Elementary School Muhammadiyah Kepahiang.

Keywords: Education, Muhammadiyah.
\end{abstract}

Abstrak: Organisasi Muhammadiyah mulai masuk ke Kepahiang sejak tahun 1926. Organisasi Muhammadiyah di Kepahiang memiliki beberapa amal usaha bidang pendidikan, mulai dari Pendidikan Dasar Hingga Pendidikan Menengah. Salah satu diantaranya adalah Sekolah Dasar Muhammadiyah di kepahiang memiliki lima pendidikan sekolah dasar yang sudah ada saat belanda masih menjajah di Kepahiang lebih tepatnya pendidikan dasar Muhammadiyah sudah ada sebelum Kemerdekaan Indonesia. Metode yang digunakan dalam penelitian ini adalah metode pendekatan Sejarah. Dalam hal ini digunakan untuk menjawab pertanyaan $(5 \mathrm{~W}+1 \mathrm{H})$. Adapun Heuristik yang di pergunakan observasi dan wawancara, selanjutnya data yang di dapatkan diverifikasi sehingga mendapatkan data yang valid.Berdasarkan atas data yang sudah diverifikasi dari berbagai sumber baik lisan maupun tulisan. Didapati bahwa Sekolah-sekolah Dasar Muhammadiyah mulai didirikan sejak tahun 1926, Sekolah yang pertama kali didirkan adalah Sekolah Rakyat Muhammadiyah. Dalam pertumbuhannya pendidikan Muhammadiyah mulai mengalami penurunan eksitensinya pada masa Orde Baru, karena pada saat itu atas intruksi Presiden untuk menegerikan sekolah-sekolah swasta sehingga banyaklah bermunculan sekolah-sekolah Negeri yang baru. Melihat kondisi ini para pengurus Muhammadiyah kab. Kepahiang berpikir keras untuk menaikkan eksitensi Sekolah Muhammadiyah lagi, salah satunya dilakukan pada Sekolah Rakyat Muhammadiyah Kepahiang yang sudah beberapa kali berganti nama, dari SR Muhammadiyah menjadi SD Muhammadiyah 05 Kepahiang hingga yang terbaru sekarang menjadi SD IT Muhammadiyah Kepahiang.

Kata Kunci: Pendidikan, Muhammadiyah.

138 NUANSA Vol. XII, No. 1, Juni 2019 
Lety Febriana, Tari Oktaviana, Surohim| Dinamika Pendidikan Dasar Muhammadiyah 139

\section{Pendahuluan}

Organisasi Muhammadiyah adalah gerakan dakwah amar makruf nahi munkar, dan gerakan tajdid yang berakidah Islam yang bersumber pada Al-Qur'an dan Sunnah. Di dirikan oleh KH. A. Dahlan pada tanggal 8 Dzulhijjah 1330 Hijriah bertepatan dengan tanggal 18 November 1912 Miladiyah di kampung kauman Kota Yogyakarta. Sebagai pendiri organisasi Muhammadiyah K.H Ahmad Dahlan juga salah tokoh Islam yang sangat peduli akan dunia pendidikan, beliau juga salah satu tokoh berpengaruh dalam dunia pendidikan, sangat sadar bahwa pendidikan merupakan dasar bagi terjadinya sebuah perubahan pada masyarakat. Tidak heran bila didalam $\mathrm{Mu}$ hammadiyah amal usaha yang paling pertama dirintis adalah bidang pendidikan, seperti halnya K.H Ahmad Dahlan membuat sebuah sekolah dirumahnya dan biaya penyelenggaraannya pun ditanggungnya sendiri.

Muhammadiyah mampu berkembang dengan baik seiring kemajuan zaman sehingga mudah diterima oleh seluruh elemen masyarakat Indonesia. Banyak hal yang mendorong kemajuan organisasi ini seperti halnya visi-misi, konsep pendidikan, tujuan, maupun kuriukulum yang saling berkesinambungan sehingga Muhammadiyah dapat berproses dengan baik dalam masyarakat. K.H. Ahmad Dahlan sangat berharap pembaharuan yang ia bawakan dapat mencerdaskan kehidupan bangsa dan memberikan pencerahan mental kepada bangsa ini.

Sekitar tahun 1920, tahun perluasan Muhammadiyah keluar Yogyakarta, manfaat dari persatuan dan dari organisasi pada umumnya telah diakui oleh sebagian besar kalangan Muslim di Indonesia. Di beberapa tempat kehadiran-kehadiran pedagang-pedagang Minangkabau yang merupakan hasil dari gerakan Pembaharuan di Minangkabau sendiri, merupakan bantuan yang sangat berharga bagi Muhammadiyah. Seperti halnya Nurul Islam Pekalongan yang didirikan oleh para pedagang ini di ubah menjadi sebuah cabang Muhammadiyah.Hingga pada Tahun 1927 Muhammadiyah mendirikan Cabang-cabang di Bengkulu, Banjarmasin, dan Amuntai, sedang pada tahun 1929 pengaruhnya tersebar ke Aceh dan Makassar. Mubaliq-mubaliq yang dikirim kedaerah-daerah tersebut dari jawa atau dari Minangkabau untuk menyebarkan Cita-cita Muhammadiyah.

Saat masuknya Muhammadiyah di kota Bengkulu terdapat banyak versi cerita atau pendapat, namun jika kita menilik syarat berdirinya Cabang Muhammadiyah saat itu yang mewajibkan calon cabang harus memiliki amal usaha minimal sudah berjalan dua tahun, maka dapat disimpulkan bahwa Madrasah Muhammadiyah yang menjadi amal usaha itu berdiri pada tahun 1926, dan muhammadiyah sendiri mendapat pengakuan dari pengurus pusat tahun 1927. Baru pada tahun 1928 SK pertama Pendirian Muhammadiyah Cabang Bengkulu diberikan. Sekarang lembaga Pendidikan ini menjadi SD Muhammadiyah 1 Kebun Ros dan sekolah tertua dikota Bengkulu. Bahkan Bung Karno sendiri saat pembuangannya di Bengkulu sempat memberikan pelajaran disekolah ini. Dan sekarang pun lembaga-lembaga pendidikan Muhammadiyah juga sudah banyak tersebar di Provinsi Bengkulu ini, salah satunya di kabupaten Kepahiang.

Ada beberapa hal yang melatar belakangi K.H Ahmad Dahlan mendirikan Muhammadiyah sebagai suatu organisasi:

1. Umat Islam tidak memegang tuntunan Alquran dan hadits Nabi sehingga menyebabkan perbuatan syirik, bid'ah dan khufarat semakin merajalela serta mencemarkan ajarannya

2. Keadaan umat Islam sangat menyedihkan akibat penjajahan

3. Kegagalan institusi pendidikan Islam untuk 
memenuhi tuntunan kemajuan zaman merupakan akibat dari mengisolasi diri.

4. Persatuan dan kesatuan umat Islam menurun sebagai akibat lemahnya Islam yang ada

5. Munculnya tantangan dari kegiatan misi zending yang dianggap mengancam masa depan umat Islam.

Masyarakat Indonesia sebelum lahirnya $\mathrm{Mu}$ hammadiyah adalah masyarakat terjajah yang jauh dari nilai-nilai ajaran Islam yang sesungguhnya. Penjajahan bangsa eropa ini membuat umat menderita baik dibidang ekonomi, budaya pendidikan, politik, dan bidang lainnya.

Dalam bidang ekonomi para penjajah tidak henti-hentinya melakukan pengurasan kekayaan pribumi secara paksa, bahkan dengan kekerasan senjata.

Sedangkan dalam bidang kemasyarakatan, penjajah sengaja membuat jurang pemisah antara kalangan bangsawan dengan rakyat kecil. ${ }^{2}$ kaum bangsawan dirayu agar menuruti kemuan penjajah dengan imbalan posisi jabatan dan keuntungan tertentu. Pada sisi lain, rakyat kecil pun diawasi oleh penjjah agar tidak memberontak, sehingga mereka diharapkan tetap tunduk dan patuh kepada penguasa yang menjajahnya. Penjajah selalu membuat politik devide et impere(pecah-belah) agar tidak ada persatuan antar umat Islam, sehingga umat Islam selalu keterbelakang.

Adapun dalam bidang budaya, para penjajah juga menyebarkan berbagai budaya yang bertentangan dengan ajaran Islam, seperti minumminuman keras, berjudi, pergaulan bebas, serta budaya negative lainnya. Para pelajar dijauhkan dari agamanya, dengn diajarkan dansa, pergaulan yang dilarang oleh agama, sekularisme, sehingga umat Islam selama bertahun-tahun,

${ }^{2}$ Kholid,Pendidikan Kemuhammadiahan, untuk SMA/SMK/MA, Surabaya: Majlis Dikdasmen PWM Jatim, 2008, h. 24

${ }^{3}$ Kholid, Pendidikan Kemuhammadiahan ........... h. 25

${ }^{4}$ Kholid, Pendidikan Kemuhammadiahan.......... h. 27 bahkan berabad-abad, tidak mampu memimpin bangsanya sendiri.

Bidang keagamaan, tidak sedikit umat Islam mencampurkan-adukan ajaran Islam dengan berbagai kepercayaan lokal yang sudah ada sebelumnya. Dalam masalah peribadatan misalnya, dikarenakan ingin mendapatkan banyak keutamaan tidak sedikit umat Islam yang menambahnambahinya dengan amalan yang tidak pernah Nabi Muhammad SAW ajarkan. Begitu halnya dengan masalah kepercayaan tidak sedikit umat Islam yang mengkultuskan guru rohani dan dukun, dan meyakini sebagai perantara yang menghubungkan manusia dan Allah Swt. ${ }^{3}$

Melihat kondisi yang serba menyedikan tentang umat Islam diindonesia inilah, maka K.H Ahmad dahlan mendirikan Muhammadiyahpada 18 November 1912. Diantara faktor-faktor yang melatarbelakangi berdirinya ;

1. Aspirasi keagamaan K.H. Ahmad Dahlan

2. Bercampur-aduknya ajaran Islam dengan ajaran lainnya

3. Tidak efisiennya lembaga-lembaga pendidikan agama Islam

4. Meningkatnya aktivitas misi Kristen

Amal usaha muhammadiyah (AUM) adalah salah satu usaha yang dibangun oleh persyarikatan untuk mencapai maksud dan tujuannya, yakni menegakkan dan menjunjung tinggi agama Islam. Semua bentuk kegiatan amal usaha Muhammadiyah harus mengarah kepada terlaksananya mksud dan tujuan persyarikatan, dan usaha pimpinan serta pengelola amal usaha berkewajiban untuk melaksanakannya.

\section{Bidang Keagamaan}

Bidang ini adalah pusat semua kegiatan $\mathrm{Mu}-$ hammadiyah serta menjadi dasar dan jiwa setiap

${ }^{2}$ Kholid,Pendidikan Kemuhammadiahan, untuk SMA/SMK/MA, Surabaya: Majlis Dikdasmen PWM Jatim, 2008, h. 24

${ }^{3}$ Kholid, Pendidikan Kemuhammadiahan .......... h. 25

${ }^{4}$ Kholid, Pendidikan Kemuhammadiahan.........., h. 27 

Lety Febriana, Tari Oktaviana, Surohim| Dinamika Pendidikan Dasar Muhammadiyah 141

amal usahanya. Terkait dengan amal usaha dibidang lain, baik pendidikan, kemasyarakan, kenegaraan, dan lain-lain. Kesemuanya tidak terpisah dari jiwa, dasar dan semangat keagamaan. Di antara usahanya adalah majelis Tarjih pada 1927, lembaga yang menghimpun ulama dalam $\mathrm{Mu}$ hammadiyah yang secara rutin melakukan permusyawaratan, memberikan fatwa, dan membuat tuntunan dalam bidang keagamaan yang sangat bermanfaat.

Selain itu, usaha dibidang keagamaan ini juga bisa dilihat dari peloporan Muhammadiyah dalam penentuan awal puasa Ramadhan dan Idul Fitri dengan metode hisab sesuai dengan perkembangan ilmu pengetahuan. Muhammadiyah juga tercatat sebagai organisasi pertama yang mendirikan mushala khusus wanita, meluruskan arah kiblat, memberikan tuntunan zakat profesi dll.

\section{Bidang Pendidikan}

Mencermati jejak K.H Ahmad Dahlan, sejak awal kiprahnya dia sangat mengutamakan pendidikan Umat. Dia berobsesi agar umat Islam menjadi umat yang berilmu, baik ilmu agama maupun ilmu umum. Tidak heran jika bidang usaha yang dirintis pertama kali adalah sebuah sekolah dirumahnya dan biaya penyelenggaraan pendidikan ditanggungnya sendiri.

Bahkan salah satu faktor penyebab lahirnya muhammadiyah adalah tidak efisiennya lembaga pendidikan diindonesia saat itu. Lembaga pendidikan yang tersedia sudah tidak memenuhi kebutuhan dan tantangan zaman lagi, sehingga isi, metode pengajaran, bahkan sistemnya juga harus dirombak.muhammadiyah mulai mendirikan sekolah yang tidak lagi memisahkan pelajaran yang dianggap sebagai ilmu agama dengan pelajaran yang dianggap sebagai ilmu umum (dunia). ${ }^{5}$

\section{Bidang Kemasyarakatan}

Hingga tahun 2005, dalam bidang kesehatan muhammadiyah memiliki 345 amal usaha, baik berupa rumah sakit umum, rumah sakit, bersalin, rumah bersalin, balai kesehatan ibu dan anak (BKIA), balai pengobatan, poliklinik, balai kesehatan, masyarakat, maupun layanan kesehatan yang lain. Dalam bidang kesejahteraan sosial, muhammadiyah telah memiliki 330 amal usaha, baik yang berbentuk panti asuhan yatim, panti jompo, balai kesehatan sosial, santunan keluarga, panti wreda/manula, panti cacat netra, maupun santunan kematian, dalam bidang ekonomi, hingga 2005 muhammadiyah memiliki 5 bank pengkreditan rakyat (BPR), 190 Baitut Tamwil Muhammadiyah, dan 808 koperasi (warga) Muhammadiyah.

\section{Bidang Politik Kewarganegaraan}

Muhammadiyah bukan suatu organisasi politik dan tidak menjadi partai politik. Meskipun demikian, dengan keyakinannya bahwa agama Islam adalah agama yang mengatur segenap kehidupan didunia ini maka dengan sendirinya segala hal yang berhubungan dengan dunia juga menjadi bidang garapnya, tak terkecuali soal-soal politik kewarganegaraan. Akan tetapi, jika ikut bergerak dalam urusan kenegaraan dan pemerintahan, muhammadiyah tetap dengan batas-batasnya sebagai gerakan dakwah Islam amar makruf dan nahi munkar, dan tidak bermaksud menjadi partai politik. ${ }^{6}$

Atas dasar itulah, K.H Ahmad Dahlan ikut duduk menjadi pengurus Budi Utomo atau menjadi penasehat pimpinn sarekat Islam. Begitu pula pemimpin-pemimpin Muhammadiyah yang lain, pada dasarnya memiliki pendirian yang sama. 


\section{Pembahasan}

\section{Konsep Pendidikan Muhammadiyah}

\section{Pendidikan dan Pengajaran}

Meskipun dalam format yang masih sangat sederhana, Pendidikan Muhammadiyah sebagai amal shalih profesional telah dilaksanakan oleh K.H Ahmad Dahlan dan para Founder Fathers pendidikan Muhammadiyah. perkembangan pendidikan Muhammadiyah mampu melaksanakan konsep amal shalih profesional ini.

Didirikan pendidikan Muhammadiyah dilandasi oleh motivasi teologios bahwa manusia akan mampu mencapai derajat keimanan dan ketaqwaan yang sempurna apabila mereka memiliki kedalaman ilmu pengetahuan. Motivasi teologis inilah yang mendorong K.H Ahmad Dahlan menyelenggarakan pendidikan di emperan rumahnya dan memberikan pelajaran agama ekstra kurikuler di OSVIA dan kweekschool.Pendidikan model Belanda yang tidak mengajarkan agama sama sekali melahirkan intelektual yang cenderung sekuler. Mereka mengusai ilmu pengetahuan modern tetapi sangat dangkal pemahaman dan pengalaman agamanya. Sebaliknya pendidikan pesantren yang hanya mengajarkan agama dan sama sekali menolak pelajaran umum menghasilkan alumni yang sangat religius, tetapi sangat kolot. Mereka sangat anti modernisitas dan tidak mampu mengikuti perkembangan zaman.

Berangkat dari realitas tersebut K.H Ahmad Dahlan mendirikan pendidikan Muhammadiyah yang didalamnya diajarkan pelajaran agama dan umum. Model pendidikan Muhammadiyah ini merupakan perpaduan antara sistem sekolah belanda dan model pesantren. Dengan model ini, pendidikan Muhammadiyah diharapkan mampu menghasilkan "ulama-intelektual" atau "intelektual-ulama", generasi yang utuh bukan generasi yang mengalami "split-personality". Agama dalam pandangan K.H Ahmad Dahlan, harus sejalan dan saling mendukung dengan ilmu pengetahuan. ${ }^{7}$

\section{b. Tujuan dan Cita-cita Pendidikan Muham- madiah}

Tujuan pendidikan merupakandas solen yang hendak dicapai melalui proses danpraktik pendidikan. Tujuan pendidikanberkaitan dengan perubahan yang diharapkanpada peserta didik setelah mengalamiproses pendidikan, baik terkait denganperkembangan pribadi maupun kehidupansosial di mana individu itu berada. Dalam kajian pendidikan, perbincangan tentangtujuan pendidikan termasuk bagian dariilmu pendidikan sistematis. ${ }^{8}$ Tujuan dari pendidikan Muhammadiyah yaitu membentuk manusia muslim yang berakhlak mulia, cakap, percaya kepada diri sendiri dan berguna bagi masyarakat. ${ }^{9}$

Di sekolah- sekolah Muhammadiyah, murid-murid ditempa untuk menjadi manusia yang berguna bagi agama, masyarakat lingkungannya, bangsa dan Negara. Jelasnya anak didik Muhammadiyah adalah merupakan kader- kader $\mathrm{Mu}$ hammadiyah di Masa yang akan datang. Pelajar Muhammadiyah disamping memperoleh pelajaran umum, juga mendapatkan ilmu- ilmu agama seperti Aqidah, Ibadah, Tarikh, Akhlak dan AlQuran lengkap dengan tajwidnya. ${ }^{10}$

Pendidikan Dasar dan Menengah Muhammadiyah bertujuan : Membentuk Manusia Muslim yang beriman, bertaqwa, berakhlak mulia, cakap, percaya pada diri sendiri, berdisiplin, bertanggung jawab, cinta tanah air, memajukan serta mengembangkan ilmu pengetahuan dan keterampilan, beramal menuju terwujudnya masyarakat utama, adil dan makmur yang diridhoi Allah SWT serta menghasilkan sumber daya manusia yang handal. ${ }^{11}$ Tujuan pendidikan $\mathrm{Mu}-$

${ }^{6}$ Kholid, Pendidikan Kemuhammadiahan.........., h. 34

${ }^{7}$ Edy Suandi Hamid, Muchlas, dkk. Membangun profesionalisme Muhammadiyah, Yogyakarta: LPTP PP Muhammadiyah, 2002, h. 102

${ }^{8}$ Mohamad Ali, Membedah Tujuan Pendidikan Muhammadiyah, Jurnal Studi Islam, Vol. 17, No. 1, Juni 2016: 43-56, H. 46 
Lety Febriana, Tari Oktaviana, Surohim| Dinamika Pendidikan Dasar Muhammadiyah 14

hammadiyah mengalami beberapa kali perubahan yang secara garis besar dapat dibagi menjadi era pra-perumusan dan era perumusan formal. Beberapa kali modifikasi yang dilakukan masih menunjukkan titik kontinuitas dengan idea pendidikan KH Ahmad Dahlan.

A. Sejarah Muhammadiyah Kabupaten Kepahiang

Organisasi Muhammadiyah sudah mulai masuk di Kepahiang sekitar tahun 1926. Dibawa dan disebarkan oleh para orang-orang padang, organisasi Muhammadiyah di Kepahiang pertama kali masuk di Desa Taba Sating, pada tahun ini juga buya Hamka pernah melakukan Kongres di desa Taba satingyang akan dihadiri oleh Ir. Soekarno namun saat dalam perjalanan ke Kepahiang Ir. Soekarno dihadang dan berhentikan oleh orang-orang Belanda, sehingga bung Karno tidak dapat melanjutkan perjalanannya, dan yang menggantikan bung Karno adalah oleh seorang pimpinan kosultan dari China, yang bernama Oei Ching Hin, seseorang keturunan China menjadi mualaf yang bertempat tinggal di Kaur. $^{12}$

Hal ini diperkuat dengan pernyataan dari Datuk Amrullah yang merupakan seorang anak dari Bpk Ma'i kepala Majelis Pendidikan Muhammadiyah dan pendapat ini juga diperkuat oleh bapak Sandi anak dari pak Dait (ia adalah seseorang yang mewakafkan tanah untuk pembangunan sekolah di taba sating) membenarkan bahwa muhammadiyah mulai masuk ditaba sat-

${ }^{9}$ Margono Poesposuwarno Sholihin, beberapa soal jawab ke-Muhammadiyahan, Yogyakarta, 1976, h. 42

${ }^{10}$ Isma Asmaria Purba, Ponirin, Perkembangan Amal Usaha Organisasi Muhammadiyah di Bidang Pendidikan dan Kesehatan, Jurnal Ilmu Pemerintahan dan Sosial Politik 1 (2) (2013): 101-111, h. 109

${ }^{11}$ ST Rajjah Rusyadi, "PERAN MUHAMMADIYAH (KONSEP PENDIDIKAN, USAHA-USAHA DI BIDANG PENDIDIKAN, DAN TOKOH)” Jurnal Tarbawi, vol 1, No. 2, h. 146

${ }^{12}$ Wawancara pak H.Hasbi informasi ini beliau dapatkan langsung dari tetangganya yang menghadiri kongres tersebut, yang sekarang telah meninggal.

${ }^{13}$ Salim bella pilli dan Hardiansyah, Napak Tilas Sejarah Muhammadiyah Bengkulu, Bengkulu: Valia Pustaka, 2016, h.222 ing sekitar tahun 1926 dan pak Hasbi yang dahulu sekitar tempat tinggalnya dalah tempat melakukan Kongres tersebut. Di Taba sating ini sendiri amal usaha yang didirikan dalam bidang pendidikan yaitu sebuah sekolah dasar, dan sebuah masjid yang bertahan hingga sekarang.

Di kabupaten Kepahiang sendiri menurut pendapat para tetua terdahulu organisasi $\mathrm{Mu}$ hammadiyah ini mulai dikenalpada tahun 1932, ini dibuktikan juga dengan SK penetapan pimpinan wilayahdalam pendataan Daerah/Cabang Muhammadiyah PWM Bengkulu, bahwa Muhammadiyah di Kabupaten Kepahiang dalam SK nya ditetapkan pada tanggal 09-03-1932. ${ }^{13}$

Selanjutnya bahwa muhammadiyah masuk dibawa oleh orang-orang Padang, walaupun belum ditemukan secara pasti dalam penyebaran muhammadiyah ini, ada banyak pendapat tentang masuknya, namun menurut para tetua terdahulu bahwa H. Abdul Rohim seseorang yang berasal dari Padang, ia adalah orang yang pertama kali mendirikan cabang Muhammadiyah di Kepahiang, dahulu cabang muhammadiyah kepahiang berinduk di Taba Penanjung dekat Masjid Muhajirin Taba Penanjung, dan sahnya cabang Muhammadiyah di Kepahiang baru pada tahun 1966.

\section{B. Dinamika Perkembangan Sekolah Muham- madiyah di kab. Kepahiang}

Dari awal masuknya Muhammadiyah pada tahun 1926 muhammadiyah sudah mulai mendirikan amal usaha dalam bidang Pendidikan, salah satu sekolah yang didirikan Muhammadi-

${ }^{9}$ Margono Poesposuwarno Sholihin, beberapa soal jawab ke-Muhammadiyahan, Yogyakarta, 1976, h. 42

${ }^{10}$ Isma Asmaria Purba, Ponirin, Perkembangan Amal Usaha Organisasi Muhammadiyah di Bidang Pendidikan dan Kesehatan, Jurnal Ilmu Pemerintahan dan Sosial Politik 1 (2) (2013): 101-111, h. 109

${ }^{11}$ ST Rajjah Rusyadi, "PERAN MUHAMMADIYAH (KONSEP PENDIDIKAN, USAHA-USAHA DI BIDANG PENDIDIKAN, DAN TOKOH)"Jurnal Tarbawi, vol 1, No. 2, h. 146

${ }^{12}$ Wawancara pak H.Hasbi informasi ini beliau dapatkan langsung dari tetangganya yang menghadiri kongres tersebut, yang sekarang telah meninggal.

${ }^{13}$ Salim bella pilli dan Hardiansyah, Napak Tilas Sejarah Muhammadiyah Bengkulu, Bengkulu: Valia Pustaka, 2016, h.222 
yah di Kepahiang pertama kali adalah sekolahsekolah tingkatan dasar atau lebih kita kenal sekarang Sekolah Dasar/SD. Dahulu pada tahun 1926 sekolah Dasar yang pertama itu didirikan bernama Sekolah Rakyat Muhammadiyah atau SR Muhammadiyah di Kepahiang, selanjutnya didirikan SMP Muhammadiyah Kepahiang, setelah SMP di Kepahiang didirikan barulah mendirikan SMA Muhammadiyah di Kepahiang yang dulu lebih dikenal dengan nama SPG Muhammadiyah atau Sekolah Guru Muhammadiyah. Selanjutnya Sekolah Dasar yangdidirikan adalah Sekolah Dasar Muhammadiyah di Taba Sating, pada tahun 1950an didirikan SD Muhammadiyah 06 Batu Bandung. ${ }^{14}$ setelah berkisar dari 3 tahun barulah di dirikan SLTP Muh. 6 Batu bandung, ${ }^{15}$ selanjutnya pada tahun 1956-1957 didirikan SD Muhammadiyah 02 di desa Punguk Meranti, selanjutnya barulah didirikan SD Muhammadiyah di Talang Kelompok kec. Muara Kemumu. Dahulu sekolah-sekolah Muhammadiyah yang telah disebutkan sangatlah terkenal dan diminati sebab dahulu kebanyakan sekolah-sekolah Muhammadiyah adalah sekolah awal yang pertama kali berdiri daripada sekolah-sekolah umum lainnya di daerah-daerah tersebut.

Selain itu tenaga pengajarnya pun masih banyak, bahkan didatangkan langsung dari Yogyakarta. Salah satu contohnya tenaga pengajar di SD Muhammadiyah 02 Kepahiang tepatnya pada tahun 1962 keatas bapak. Ma'i (ka. Majlis Pendidikan Muhammadiyah ) berangkat ke jogja hanya untuk menjemput langsung orang-orang yang cocok untuk menjadi guru Muhammadiyah, seperti bapak Badrun, Bapak Padari (yang mendirikan HW). ${ }^{16}$

Dari bebrapa sekolah yang Muhammadiyah didirikan, sepertiyang telah disebutkan, sekarang hanya tinggal beberapa sekolah yang masih bertahan bebrapa sekolah sudah banyak yang tidak aktif lagi atau sudah mati, itu di karenakan sudah banyak bermunculan sekolah-sekolah Negeri yang didirikan pemerintah, tepatnya pada tahun 1973 - 1989) saat menjabatnya Presiden Soeharto atau pada zaman orde baru mulai bermunculan sekolah-sekolah INPRES atau Intruksi Presiden, bahwa sekolah-sekolah swasta harus di negrikan, Sehingga sekolah - sekolah pemerintah lebih di minati dibandingkan sekolah-sekolah swasta seperti halnya sekolah Muhammadiyah.

Selain dari sekolah-sekolah Muhammadiyah di daerah Kepahiang yang bebrapa sudah tidak aktif lagi atau yang sudah mati. Di masa sekarang Muhammadiyah sudah mulai melakukan penggebrakan, pergerakan dalam bidang pendidikan salah satu contohnya adalah SD IT Muhammadiyah Kepahiang dan pada tahun ini juga akan dibangun Madrasah Ibtida'iyah Muhammadiyah di desa Talang Karet kabupaten Kepahiang. ${ }^{17}$

\section{Faktor Penghambat dan Pendukung}

Dalam setiap perkembangan dari awal berdiri pasti selalu ada yang namanya faktor penghambat dan faktor pendukung, seperti yang kita ketahui bahwaorganisasi Muhammadiyah ini, bukan sebuah organisasi yang baru apalagi dalam pemurniannya, ketika ajaran agama ingin kembalikan ke ajaran yang sebenar-benarnya bukan hal yang mudah, apalagi masyarakat sudah terbiasa mengikuti kebiasaan-kebiasaan lama dari nenek moyang terdahulu.

Selain dari organisasinya sendiri dalam bidang pendidikan pun demikian, karena sesuatu hal itu tidak selalu berjalan lancar-lancar saja. Sepertihalnya organisasi Muhammadiyah di Kepahiang, ada beberapa faktor yang menghambat dan mendukung dalam perkembangannya diantaranya :

\footnotetext{
${ }^{14}$ Wawancara pak Bahrin, PCM di Batu Bandung

${ }^{15}$ Wawancara ibu. Rika (wakil kepala sekolah SD Muh. 06 Batu Bandung) kan)
} 
Lety Febriana, Tari Oktaviana, Surohim| Dinamika Pendidikan Dasar Muhammadiyah 145

\section{a) Faktor Pendukung}

Menurut bspsk Sholihin bahwa Muhammadiyah di Kepahiang sudah maju, sudah ada banyak amal usaha, pembanguan, pengurus $\mathrm{Mu}$ hammadiyah pun masih ada hingga sekarang, bahkan bertambah, dalam pembangunan-pembangun Muhmmadiyah sudah banyak membangun sekolh-sekolah, dan dari informasi terakhir Muhammadiyah sekarang sedang mendirikan MI Muhammadiyah di desa talang karet. ${ }^{18}$

\section{b) Faktor Penghambat}

Menurut bapak Hasan Samrin, bahwa sejak awal berdirinya Muhammadiyah sudah mendapatkan halangan dari para penjajah, karena $\mathrm{Mu}$ hammadiyah menjadi penghalang organisasi mereka terbebaskan. Seperti halnya yang dikatakan oleh bapak Zulkarnain Rifai, seperti yang kita ketahui bahwa Muhammadiyah masih dipandang sebelah mata, dimata masyarakat $\mathrm{Mu}$ hammadiyah dianggap agama yang baru, ${ }^{19}$ dan organisasi Muhammadiyah belum diterima sepenuhnya, namun bukan berarti Muhammadiyah ditolak. Seperti halnya kebiasaan masyarakat tentang masalah kematian, tahlilan dan sebagainya.

Dalam bidang pendidikan ada beberapa faktor pendukung dan faktor penghambat dalam perkembangan pendidikanMuhammadiyah di kab. Kepahiang diantaranya :

\section{a) Faktor Pendukung,}

Dalam hal ini menurut bapak Sholihin PC Muhammadiyah 1995 -2000 Masih ada beberapa orang yang mau bersekolah di sekolah-sekolah Muhammadiyah walaupun itu hanya beberapa dan hanya orang-orang yang berjiwa Muhammadiyah, dari beberapa sekolah yang diteliti bahwa Sekolah-sekolah Muhammadiyah tidak membebankan biaya terhadap siswanya, selan-

${ }^{17}$ Wawancara bapak Drs. Abdul Rokhim (Ka. PDM Kepahiang)

${ }^{18}$ BapakWawancara bapak Drs. Abdul Rokhim (Ka. PDM Kepahiang) ${ }^{19}$ Wawancara bapak. Zulkarnaim Rifa'i jutnya Masih ada beberapa guru/ tenaga pendidik yang mau mengajar secara ikhlas. ${ }^{20}$ dan Sebagian besar Alumni atau lulusan dari sekolah-sekolah Muhammadiyah sudah menjadi orang yang sukses, terpandang bahkan sudah mempunyai jabatan tinggi.

\section{b) Faktor Penghambat}

Dalam perkembangan pendidikan Muhammadiyah di kab. Mempunyai beberapa faktorfaktor yang menghambat perkembangannya, sehingga ada beberapa sekolah yang tidak bisa bertahan hingga sekarang. Seperti halnya pendapat dari bapak. Supriadi bahwa Sekolah muhammadiyah kalah bersaing dengan sekolahsekolah negeri, Selanjutnya kurang ikut andilnya sekolah-sekolah lain dikab. Kepahiang dalam mendukung sekolah-sekolah swasta, sehingga sekolah Muhammadiyah di Kepahiang tidak selalu dianggap sekolah buangan. Seperti halnya untuk sekolah lain di Kepahiang membatasi setiap penerimaan siswa/siswi baru. ${ }^{21}$

Selanjutnya menurut bapak Sholihin bahwa Sekolah-sekolah Muhammadiyah kurang diminati dikarenakan Masih ada sebagian orang yang memandang sebelah mata tentang pendidikan di Muhammadiyah, tanpa memandang kualitasnya, $^{22}$ apalagi seperti yang dikatakan bapak Supriadi bahwa, tidak ikut andilnya anggota Muhammdiyah dalam memajukan sekolahsekolah tersebut. Contohnya sebagian dari anggota muhammadiyah terkadang enggan untuk menyekolahkan anaknya disekolah-sekolah $\mathrm{Mu}$ hammadiyah itu sendiri, Kurangnya perhatian pusat terhadap sekolah-sekolah muhammadiyah di Perdalaman, selanjutnya Pihak yayasan itu sendiri tidak ada yang ingin mensubsidikan sekolah-sekolah tersebut, banyak keinginan namun tidak ada pergerakan. ${ }^{23}$

Untuk sekolah-sekolah di pedesaan atau pedalaman sekolah muhammadiyah tidak adanya bantuan dari atasan/yayasan, sehingga tidak 
ada perbaikan pembangunan sekolah itu sendiri, tenaga pengajarnya pun hanya mengandalkan dana BOS untuk gaji mereka. Dan dana BOS itu sendiri sedikit banyaknya tergantung atas banyak siswa/i-nya, ${ }^{24}$

hal ini juga dibenarkan oleh ibu wika wakil kepala sekolah SD Muhammadiyah 06 Batu Bandung selain itu menurutnya Kurangnya tenaga pengajar di sekolah-sekolah Muhammadiyah itu sendiri terkhusus tenaga pendidik di pedesaan atau pedalaman, karena tempat yang jauh sehingga para guru susah untuk mengakses buku-buku pembelajaran terkhusus bidang pendidikan kemuhammadiahan, sehingga masih kurangnya buku-buku Pembelajaran, yang paling penting Seharusnya perlu pengelolan yang baik sehingga hiduplah sekolah tersebut.

\section{Dinamika Pendidikan Dasar Muhammadi- yah di SD Muhammadiyah 05 Kepahiang}

Organisasi Muhammadiyah mulai masuk ke Kepahiang sekitaran tahun 1926. Seperti halnya yang kita ketahui bahwa sekitar tahun 1920, tahun perluasan Muhammadiyah keluar Yogyakarta, ${ }^{25}$ Hingga pada Tahun 1927 Muhammadiyah mendirikan Cabang-cabang Di Bengkulu, Banjarmasin, dan Amuntai, sedang pada tahun 1929 pengaruhnya tersebar ke Aceh dan Makassar. Dalam penyebarannya, organisasi Muhammadiyah di Kepahiang dibawa atau disebarkan oleh para orang-orang Minangkabau, walaupun banyak pendapat mengenai penyebaran organisasi Muhammadiyah di Kepahiang ini, mulai dari pendapat pak Salim Bela Pili bahwa muhammadiyah dibawa oleh orang-orang jawa dan bahkan ada temuan terbaru ditemukannya ketikan sejarah oleh orang-orang Serawai,

${ }^{20}$ Bapak sholihin mantan k.a PC Muhsammadiyah Punguk Meranti tahun 1995-2000

${ }^{21}$ Wawancara bapak Supriadi (ka. SMA Muh. Kepahiang)

${ }^{22}$ Bapak sholihin mantan k.a PC Muhsammadiyah Punguk Meranti tahun 1995-2000

${ }^{23}$ Wawancara bapak Supriadi (ka. SMA Muh. Kepahiang )

${ }^{24}$ Ibu Maryana Kepala Sekolah SD Muhammadiyah 02 Punguk Meranti
Talo Bengkulu Selatan pada tahun 1970an. Namun dalam kenyataannya penyebaran Muhammadiyah yang dibawa oleh orang Talo Bengkulu Selatan tidak ditemukan, orang-orang Serawai masuk Kekepahiang karena imigrasi dari Talo, di gunung semidang bukit kabu karena kehidupan disana sudah mulai dan kepahiang memiliki tanah yang masih subur sehingga masuklah orang Serawai ke Tapak Gedung, Talang Karet, ke Bumi Sari, hingga sampai sekarang menyebarlah suku Serawai di kabupaten Kepahiang $\cdot{ }^{26}$

ApalagibahwaMubaliq-mubaliqyang dikirim kedaerah-daerah tersebut berasal dari jawa atau dari Minangkabau untuk menyebarkan Cita-cita Muhammadiyah. ${ }^{27}$

Pendapat lainnya yang lebih kuat organisasi Muhammadiyah dibawa oleh orang Minangkabau adalah bahwa Pendiri Cabang pertama kali di Kepahiang adalah H. Abdul Rohim ia adalah seorang keturunan orang Minangkabau yang berasal dari PadangSumatra Barat. Dahulu cabang Muhammadiyah di Kepahiang berinduk di Taba Penanjung dekat Masjid Muhajirin Taba Penanjung, dan sahnya cabang Muhammadiyah di Kepahiang baru pada tahun $1966 .^{28}$

Awalkalimasuknya organisasi Muhammadiyah di Kepahiang tepatnya di Desa Taba Sating pada tahun 1926, ditahun ini juga dahulu Buya Hamka pernah melakukan Kongres di Taba Sating. ${ }^{29}$ Pada saat peresmiannya cabang Muhammadiyah di Taba Sating, hal ini juga dibenarkan oleh PC Muhammadiyah taba sating (anak dari datuk Dait pewakaf tanah sekolah Muhammadiyah Taba Sating) dan ini juga diterangkan oleh bapak Abdul Rokhim (PDM Kepahiang) bahwa bahwa dalam perencanaannya akan diresmikan oleh Ir. Soekarno namun saat dalam perjalanan ke Kepahiang tepatnya jalan Lintas BengkuluKepahiang digunung, Ir. Soekarno dihadang dan berhentikan oleh orang-orang Belanda, sehingga bung karno tidak dapat melanjutkan perjalanannya, dan selanjutnya yang meresmikan cabang 
Lety Febriana, Tari Oktaviana, Surohim| Dinamika Pendidikan Dasar Muhammadiyah

Muhammadiyah di taba sating pun digantikan oleh seorang pimpinan kosultan dari China. ${ }^{30}$ Di Taba Sating sendiri bangunan sejarah yang masih dapat dijumpai hingga sekarang adalah adanya bangunan Masjid dan Gedung SD Muhammadiyah.

Masjid ini adalah salah satu masjid Muhammadiyah di Desa taba Sating, sebenarnya ada satu lagi masjid di desa ini tepatnya berada, disamping sekolah dasar Muhammadiyah namun karena sekarang Taba Sating sudah melakukan Pemekaran, yang mana desa ini sekarang sudah dibagi dua menjadi Taba Sating dan Taba Saling. Sehingga satu masjid berada di taba saling dan satunya lagi, sekolah berada di Taba Sating. Dan masjid ini juga salah satu bukti sejarah Muhammadiyah di taba sating ini.

Seperti yang kita ketahui bahwa tempat ibadah atau masjid adalah bangunan yang terlebih dahulu dibangun dalam organisasi $\mathrm{Mu}$ hammadiyah. pada tahun 1926 ini juga organisasi Muhammadiyah di Kepahiang mendirikan sebuah Masjid yang dinamai Masjid Taqwa. Dahulu masjid taqwa berada dipinggir jalan sekarang sudah menjadi gerbang Masjid Taqwa, dahulu Masjid Taqwa berukuran kecil hanya 8 x 9 karena perkembangan dan jamaahnya yang semakin meningkat sehingga dibangunlah hingga kebelakang, orang yang mewakafkan tanahnya untuk pembangunan masjid ini adalah $\mathrm{H}$. Abdul Rokhim ia juga orang yang mendirikan Cabang pertama di Kepahiang. Surat wakaf pun masih ada hingga sekarang, walaupun pernah hilang saat agresi militer belanda namun pada tahun 1960 surat wakaf ini kembali dibuat dan termasuk didalamnya ditanda tangani oleh bapak H. Abdul Rohim itu sendiri, dan surat wakaf ini juga membuktikan bahwa organisasi Muhammadiyah sudah ada sejak 1932.

Dalam perkembangan organisasi Muhammadiyah di Kepahiang bangunan yang paling pertama didirikan adalah Masjid. Selain Masjid, amal usaha Muhammadiyah lainnya di Kepahiang yaitu dalam bidang Pendidikan. Dalam bidang ini Muhammadiyah banyak mendirikan sekolah-sekolah mulai dari tingkatan Anak Usia Dini, Sekolah Dasar, Sekolah Menengah Pertama Dan Sekolah Menengan Atas. Diawal berdiri Muhammadiyah mendirikan beberapa sekolah, dalam tingkatan Sekolah Dasar sekolah Muhammadiyah salah satunya adalah SD Muhammadiyah 05 Kepahiang.

Sekolah ini didirikan pada tanggal 5 Agustus $1926^{31}$ namun dalam SK Pendiriannya baru ditetapkan pada tahun 1928 beralamatkan di jln. Kol. Santoso No.282 Kepahiang ${ }^{32}$ dengan nama awal berdiri sebagai Sekolah Rakyat Muhammadiyah atau lebih dikenal dengan SR Muhammadiyah. Sekolah ini adalah sekolah pertama yang didirkan pada saat itu di daerah Kepahiang dan sekolah Muhammadiyah ini juga yang paling tua diantara sekolah Muhammadiyah lainnya di kabupaten Kepahiang.

SR Muhammadiyah ini pertama kali didirikan oleh Buya Hamka, dan Buya Hamka juga pernah mengajar di SR Muhammadiyah Kepahiang dahulu. ${ }^{33}$ Hal ini juga dibenarkan oleh bapak H. M. Hasbi mantan PC Muhammadiyah Taba Santing bahwa Buya Hamka memang benar pernah ke daerah Kepahiang, tepatnya pada tahun 1939 buya Hamka pernah menghadiri sebuah kongres Muhammadiyah di taba sating Kepahiang yang dihadiri juga oleh Oei Ching Hin seorang konsul China, Ir. Soekarno.

Dahulu Tenaga Pendidik di Sekolah Muhammadiyah di jemput langsung dari Yogyakarta, dijemput oleh bpk. Ma'i Kepala Majelis Pendidikan dan Kebudayaan Muhammadiyah terdahulu. Yang didatangkan langsung dari Jogja diantaranh.173

${ }^{25}$ Zuhairini, dkk. Sejarah Pendidikan Islam, Jakarta : Bumi Aksara, 2008,

${ }^{26}$ Wawancara Bapak Drs. A. Rokhim ${ }^{27} \mathrm{Ibid}, \mathrm{h} .175$

${ }^{28}$ Wawancara bapak Abdul Rokhim (ketua PDM kepahiang),

${ }^{29}$ Wawancara bpk. H. Zulkarnain Rifai

${ }^{30}$ Informasi dari bapak. Zulkarnain, 
ya; Pak Badrun, Bapak Pedari (yang mendirikan Hisbul Wathan di Kepahiang). ${ }^{34}$

Sebelum dipindahkan ke area komplek Masjid Taqwa, letak SR Muhammadiyah dahulu berada di pinggir jalan tepatnya dibarisan ruko, karena kegiatan ekonomi dan pembangunan sehingga dipindahkan. Gedung SR muhammadiyah sekarang lebih dikenal dengan warnet Lentera.

Pada tahun 1987 karena perkembangan dan kegiatan ekonomi sehingga gedung sekolah SR Muhammadiyah dilakukan perombakan dan SR Muhammadiyah ini dipindahkan ke area kiri Kompleks Majid Taqwa kepahiang jln. Kol. Santoso no. 282 tanah yang diwakafkan oleh bapak H. Abdul Rohim. ${ }^{35}$

Awal dipindahkan sekolah ini hanya mempunyai 3 kelas saja, namun karena perkembangan zaman dan pembangunan sehingga sekolah ini sudah mempunyai beberapa kelas yang baru.

SD Muh. 05 Kepahiang ini sudah beberapa kali melakukan pergantian Kepala Sekolah diantaranya:

1. Ibu Suhatri

2. Pak Sulana

3. Ibu Saminah

4. Pak Sukarmin Hadi Santoso (sekarang)

Perkembangannya zaman ketika sekolahsekolah tingkatan dasar mulai bermunculan, dan pada tahun 1974-1989 muncullah InPres atau intruksi presiden untuk menegrikan sekolah-sekolah swasta, dan pada akhirnya sekolah-sekolah Muhammadiyah sudah mulai kurang diminati, karena kalah bersaing dengan sekolah negeri lainnya.Karena keterbatasan dokumen arsip sekolah sehingga tidak tahu pasti berapa banyak siswa terdahulu. Namun dari data terakhir yang

\footnotetext{
${ }^{31}$ Wawancara bapak. Drs Abdul Rokhim

${ }^{32}$ Ibu suminah (k.a SD Muh. 05 Kepahiang ) dan SK Pendirian dari PDM

${ }^{33}$ Wawancara bpk. Zulkarnain

${ }^{34}$ Datuk Ambrullah anak dari bapak Ma'i ka.majelis Pendidikan dan Kebudayaan
}

didapatkan, Menurut ibu Saminah S. Pd sekitar tahun 1990an jumlah siswa masih sekitar 30an dan sekitar pada tahun 2012-2013 baru meningkat hampir 100an siswa ${ }^{36}$ namun pada tahun berikutnya siswa/i sedikit-sedikit mulai berkurang dan guru pun hanya tinggal beberapa lagi.

Karena melihat kondisi SD Muhammadiyah 05 yang memperhatinkan ini dengan murid yang terbatasseperti ini, tepatnya pada bulan februari 2018 para anggota PDM berembuk atau bermusyawarah untuk kemajuan SD Muhammadiyah ini . Sehingga dari hasil musyawarah itu muncullah sebuah gagasan untuk mengubah SD Muhammadiyah 05 menjadi SD IT Muhammadiayah.

Selain itu perubahan itu didasari juga, karena melihat dari majunya SD IT Cahaya Rabbani pasar ujung Kepahiang, serta SD ITAisiyah $\mathrm{Cu}-$ rup. Sebenarnya dahulu rencananya ingin membuka sekolah baru yaitu SDIT muhammadiyah namun karena melihat kondisi dan tempat yang tidak memadai, jika dibangun 1 sekolah $\mathrm{Mu}$ hammadiyah lagi di Kepahiang maka SD Muhammadiyah 05 Kepahiang ini akan mati.

Sehingga tepatnya dibulan Juni 2018, pada tahun ajaran baru 2018/2019 dari SD Muhammadiyah 05 Kepahiang berganti menjadi SD IT Muhammadiyah. Dan sekarang SD IT Muhammadiyah sudah berumur 2 bulan, dan diawal pembukaannya SD ini sudah 20 siswa yang di terima.

a. Visi dan Misi SD Muhammadiyah 05 Kepahiang

\section{1) Visi SD Muhammadiyah 05 Kepahiang}

Membentuk sekolah yang Islami, berbudi luhur dan berakhlakul karimah.

\section{2) Misi SD Muhammadiyah 05 Kepahiang}

a) Membentuk generasi yang sholeh dan sholehah

\footnotetext{
${ }^{35}$ Wawancara bapak Drs. Abdul Rokhim kepala PDM Kepahiang ${ }^{36}$ Ibu Saminah

${ }^{37}$ Wawancara bapak Gusti Santoso S.P
} 
Lety Febriana, Tari Oktaviana, Surohim| Dinamika Pendidikan Dasar Muhammadiyah

b) Memdidik siswa dan siswi berdasarkan IPTEK dan IMTAQ

c) Membentuk karakter bakat sesuai kemampuan dan keahlian yang dimiliki siswa dan siswi SD Muhammadiyah 5 Kepahiang

d) Menjalin hubungan kerja sama dengan pihak Dinas Pendidikan dan Kebudayaan Kabupaten Kepahiang dan Majelis Dikdasmen Muhammadiyah 5 Kepahiang serta sekolahsekolah yang ada di kabupaten Kepahiang dan sekitarnya

e) Sanggup mengemban tugas dan bertanggung jawab mengelola amal usaha Muhammadiyah.

\section{b. Struktur Kurikulum}

Struktur kurikulum merupakan pola dan susunan mata pelajaran yang harus ditempuh oleh peserta didik pada satuan pendidikan dalam kegiatan pembelajaran. susunan mata pelajaran tersebut terbagi dalam 5 kelompok yaitu ; kelompok mata pelajaran agama dan Akhlak Mulia, Kewarganegaraan dan Kepribadian, Ilmu Pengetahuan dan Teknologi, Estetika, Jasmani Olahraga dan Kesehatan.

Struktur kurikulum Sekolah SD Muhammadiyah 05 Kepahiang meliputi subtansi pembelajaran yang ditempuh dalam satu jenjang pendidikan selama 6 tahun mulai kelas I sampai dengan VI. ${ }^{38}$

\begin{tabular}{|c|c|c|c|c|c|c|}
\hline \multirow{2}{*}{ Komponen } & \multicolumn{6}{|c|}{ Kelas Dan Alokasi Waktu } \\
\hline & I & II & III & IV & $\mathbf{V}$ & VI \\
\hline \multicolumn{7}{|l|}{ A. Mata Pelajaran } \\
\hline 1 Pendidikan Agama & 2 & 2 & 2 & 3 & 3 & 3 \\
\hline 2 Pendidikan Kewarganegaraan & 2 & 2 & 2 & 2 & 2 & 2 \\
\hline 3 Bahasa Indonesia & 6 & 6 & 6 & 6 & 6 & 6 \\
\hline 4 Matematika & 6 & 6 & 6 & 6 & 6 & 6 \\
\hline 5 Ilmu Pengetahuan Alam & 4 & 4 & 4 & 4 & 4 & 4 \\
\hline $6 \quad$ Ilmu Pengetahuan Sosial & 2 & 2 & 3 & 3 & 3 & 3 \\
\hline 7 Kertakes & 2 & 2 & 2 & 4 & 4 & 4 \\
\hline 8 Penjaskes & 2 & 2 & 3 & 3 & 3 & 3 \\
\hline \multicolumn{7}{|l|}{ B. Muatan Lokal } \\
\hline Bahasa Inggris & 2 & 2 & 2 & 2 & 2 & 2 \\
\hline \multicolumn{7}{|l|}{ C. Pengembangan Diri } \\
\hline 1 Pramuka & & & & & & \\
\hline 2 Pencak Silat & & & & & & \\
\hline 3 Sepak Takraw & & & & & & \\
\hline Jumlah & 28 & 28 & 30 & 33 & 33 & 33 \\
\hline
\end{tabular}

SD 05 Muhammadiyah pada tahun sebelumnya menggunakan kurikulum KTSP, namun saat masuk tahun ajaran 2018/2019 dan berubah nama menjadi SD IT Muhammadiyah, sekolah ini menggunakan K.13. ${ }^{39}$

\section{c. Daftar Pendidik dan Tenaga Kependidikan}

\begin{tabular}{|c|l|c|c|l|l|l|}
\hline No & \multicolumn{1}{|c|}{ Nama } & NUPTK & JK & $\begin{array}{l}\text { Status } \\
\text { Kepegawaian }\end{array}$ & Jenis PTK & $\begin{array}{l}\text { TMT } \\
\text { Kerja }\end{array}$ \\
\hline $\mathbf{1}$ & $\begin{array}{l}\text { Sutarmin Hadi } \\
\text { Santosa }\end{array}$ & - & L & GTY/PTY & $\begin{array}{l}\text { Kepala } \\
\text { Sekolah }\end{array}$ & $\begin{array}{l}2018-07- \\
01\end{array}$ \\
\hline $\mathbf{2}$ & Saminah & 6360745647300053 & P & GTY/PTY & Guru Kelas & $\begin{array}{l}1991-07- \\
17\end{array}$ \\
\hline $\mathbf{3}$ & $\begin{array}{l}\text { Jumadi } \\
\text { Aisyah }\end{array}$ & 6739761664300012 & P & GTY/PTY & Guru Kelas & $\begin{array}{l}2004-06- \\
17\end{array}$ \\
\hline $\mathbf{4}$ & Arpan Sapari & 7244762666200003 & L & GTY/PTY & $\begin{array}{l}\text { Guru } \\
\text { Mapel }\end{array}$ & $\begin{array}{l}2008-01- \\
18\end{array}$ \\
\hline $\mathbf{5}$ & Eni Lasmita & - & P & $\begin{array}{l}\text { Honor Daerah } \\
\text { TK.II } \\
\text { Kab/Kota }\end{array}$ & Guru Kelas & $\begin{array}{l}2011-11- \\
11\end{array}$ \\
\hline $\mathbf{6}$ & Eka Susanti & - & P & GTY/PTY & Guru Kelas & $\begin{array}{l}2015-01- \\
02\end{array}$ \\
\hline $\mathbf{7}$ & Romi Sopian & - & L & GY & $\begin{array}{l}\text { Guru } \\
\text { Mapel }\end{array}$ & $\begin{array}{l}2018-07- \\
16\end{array}$ \\
\hline $\mathbf{8}$ & $\begin{array}{l}\text { Rahyan } \\
\text { Effendi }\end{array}$ & - & L & GY & $\begin{array}{l}\text { Guru } \\
\text { Mapel }\end{array}$ & $\begin{array}{l}2018-08- \\
15\end{array}$ \\
\hline $\mathbf{9}$ & Fenti Febriani & - & P & GY & $\begin{array}{l}\text { Guru } \\
\text { Mapel }\end{array}$ & $\begin{array}{l}2018-07- \\
16\end{array}$ \\
\hline $\mathbf{1 0}$ & Sri Hartati & - & P & GY & Guru Kelas & $\begin{array}{l}2018-07- \\
16\end{array}$ \\
\hline $\mathbf{1 1}$ & $\begin{array}{l}\text { Nur Halimah } \\
\text { Mazidah }\end{array}$ & - & P & GY & Guru Kelas & $\begin{array}{l}2018-07- \\
16\end{array}$ \\
\hline $\mathbf{1 2}$ & Titik Solekah & - & P & GY & $\begin{array}{l}\text { Guru } \\
\text { Mapel }\end{array}$ & $\begin{array}{l}2018-07- \\
16\end{array}$ \\
\hline $\mathbf{1 3}$ & $\begin{array}{l}\text { Dela Novika } \\
\text { Putri H. }\end{array}$ & - & P & GY & Guru Kelas & \\
\hline
\end{tabular}

Pada tahun 2015 data pendidik dan tenaga kependidikan SD Muhammadiyah Kepahiang hanya mempunyai 7 tenaga pengajar. Pada tahun 2018 saat SD Muh ini berganti menjadi SD IT Muhammadiyah tenaga pengajar menjadi 13 tenaga pengajar. ${ }^{40}$

\section{d. Analisis Kebutuhan Guru dan Karyawan}

\begin{tabular}{|c|l|c|c|c|c|c|c|}
\hline No & $\begin{array}{l}\text { Mata } \\
\text { Pelajaran/Tugas }\end{array}$ & $\begin{array}{c}\text { Jumlah } \\
\text { jam }\end{array}$ & Dibutuhkan & Ada & Kurang & Lebih & Ket \\
\hline 1 & $\begin{array}{l}\text { Penididikan } \\
\text { Agama Islam }\end{array}$ & 24 & 2 & 1 & 1 & - & GY \\
\hline 2 & Guru Kelas & 24 & 6 & 5 & 1 & - & GY \\
\hline 3 & Bahasa Inggris & 24 & 2 & 0 & 2 & - & GY \\
\hline 4 & Penjaskes & 24 & 1 & 0 & 1 & - & - \\
\hline 5 & TIK & 24 & 2 & - & 2 & - & \\
\hline 6 & Bahasa Arab & 24 & 2 & 1 & 1 & - & \\
\hline 7 & Staf TU & & 1 & 0 & 1 & - & \\
\hline 8 & Cleaning Service & & 1 & 0 & 1 & - & \\
\hline 9 & Penjaga/Staf TU & & 1 & 0 & 1 & - & \\
\hline 10 & $\begin{array}{l}\text { Petugas } \\
\text { Keamanan }\end{array}$ & 2 & 0 & 2 & - & \\
\hline 11 & Tukang Kebun & & 1 & 0 & 1 & - & \\
\hline Jumlah & & $\mathbf{2 1}$ & 7 & $\mathbf{1 4}$ & - & - \\
\hline
\end{tabular}

${ }^{38}$ Data dari KTSP SD Muhammadiyah 05 Kepahiang tahun 2007 ${ }^{39}$ Wawancara ibu saminah dan pak. Gusti 


\section{e. Data Siswa dan Wali Kelas}

\begin{tabular}{|c|l|c|c|c|c|c|c|c|}
\hline No & \multirow{2}{*}{$\begin{array}{l}\text { Nama } \\
\text { Rombel }\end{array}$} & $\begin{array}{l}\text { Tingkat } \\
\text { Kelas }\end{array}$ & \multicolumn{2}{|l|}{ Jumlah Siswa } & \multicolumn{1}{l}{$\begin{array}{l}\text { Wali } \\
\text { Kelas }\end{array}$} & Kurikulum & Roangan \\
\hline 1 & $\begin{array}{l}\text { KELAS } \\
1\end{array}$ & 1 & 11 & 9 & 20 & $\begin{array}{l}\text { Nur } \\
\text { Halimah } \\
\text { Mazidah }\end{array}$ & $\begin{array}{l}\text { Kurikulum } \\
13\end{array}$ & $\begin{array}{l}\text { Ruang Kelas } \\
1\end{array}$ \\
\hline 2 & $\begin{array}{l}\text { KELAS } \\
2\end{array}$ & 2 & 2 & 2 & 4 & $\begin{array}{l}\text { Sri } \\
\text { Hartati }\end{array}$ & $\begin{array}{l}\text { Kurikulum } \\
13\end{array}$ & $\begin{array}{l}\text { Ruang Kelas } \\
2\end{array}$ \\
\hline 3 & $\begin{array}{l}\text { KELAS } \\
3\end{array}$ & 3 & 8 & 5 & 13 & $\begin{array}{l}\text { Eni } \\
\text { Lasmita }\end{array}$ & $\begin{array}{l}\text { Kurikulum } \\
13\end{array}$ & $\begin{array}{l}\text { Ruang kelas } \\
3\end{array}$ \\
\hline 4 & $\begin{array}{l}\text { KELAS } \\
4\end{array}$ & 4 & 2 & 4 & 6 & $\begin{array}{l}\text { Jumadi } \\
\text { Aisyah }\end{array}$ & $\begin{array}{l}\text { Kurikulum } \\
13\end{array}$ & $\begin{array}{l}\text { Ruang Kelas } \\
4\end{array}$ \\
\hline 5 & $\begin{array}{l}\text { KELAS } \\
5\end{array}$ & 5 & 3 & 3 & 6 & Saminah & $\begin{array}{l}\text { Kurikulum } \\
13\end{array}$ & $\begin{array}{l}\text { Ruang Kelas } \\
5\end{array}$ \\
\hline 6 & $\begin{array}{l}\text { KELAS } \\
6\end{array}$ & 6 & 5 & 3 & 8 & $\begin{array}{l}\text { Eka } \\
\text { Susanti }\end{array}$ & $\begin{array}{l}\text { Kurikulum } \\
13\end{array}$ & $\begin{array}{l}\text { Ruang Kelas } \\
6\end{array}$ \\
\hline
\end{tabular}

\section{f. Daftar Buku Pelajaran}

\begin{tabular}{|c|l|c|c|c|c|c|c|c|c|c|}
\hline \multirow{2}{*}{ No } & \multicolumn{7}{|c|}{ Buku Pelajaran } & \multirow{2}{*}{ Ket } \\
\cline { 2 - 9 } & \multicolumn{1}{|c|}{ Nama Buku } & I & II & III & IV & V & VI & & \\
\hline 1 & Pendidikan Agama & 20 & 6 & 13 & 6 & 6 & 8 & 59 & \\
\hline 2 & Kewarganegaraan & 20 & 6 & 13 & 6 & 6 & 8 & 59 & \\
\hline 3 & $\begin{array}{l}\text { Bahasa dan Sastra } \\
\text { Indonesia }\end{array}$ & 20 & 6 & 13 & 6 & 6 & 8 & 59 & \\
\hline 4 & Bahasa Inggris & 20 & 6 & 13 & 6 & 6 & 8 & 59 & \\
\hline 5 & Matematika & 20 & 6 & 13 & 6 & 6 & 8 & 59 & \\
\hline 6 & Pendidikan Jasmani & & & & & & & 0 & \\
\hline 7 & $\begin{array}{l}\text { Teknologi } \\
\text { Informasi }\end{array}$ & & & & & & & 0 & \\
\hline 8 & BahaBahasa Arab & & & & & & & 0 & \\
\hline
\end{tabular}

\section{Penutup}

Dalam pertumbuhannya dahulu sekolah muhammadiyah adalah sekolah rujukan bagi para masyarakat, itu disebabkan Sekolah-sekolah Muhammadiyah adalah sekolah pertama yang ada di Kepahiang saat sekolah-sekolah negeri dan sekolah lainnya bermunculan. Namun pada saat memasuki masa Orde Baru pada tahun 1973 atas Intruksi Presiden untuk menegerikan semua sekolah-sekolah swasta dan bermunculanlah sekolah-sekolah Inpres.Sehingga sekolah-sekolah Muhammadiyah kehilangan eksetensinya, dan itu menyebabkan peminat atau orang-orang yang menyekolalahkan anakanaknya di sekolah Muhammadiyah berkurang setiap tahunnya. Hingga pada tahun 1969 salah satu SD Muhammadiyah di Tabasating tidak aktif lagi karena tidak ada lagi yang mendaftar di sekolah tersebut.

Ada beberapa gagasan yang dilakukan para pengurus Muhammadiyah terkhusus ka. Dikdasmen Kepahiang untuk memajukan lagi Sekolah

${ }^{40}$ Data dari SD IT Muhammadiyah Kepahiang
Muhammadiyah salah satunya muncul gagasan mengubah SD Muhammadiyah menjadi SD IT Muhammadiyah. tepatnya pada tahun 2018 bulan Juni SD Muhammadiyah 05 di ubah menjadi SD IT Muhammadiyah.Selanjutnya yang harus diketahui bahwa Dalam perkembangan sekolah ini banyak melahirkan lulusan-lulusan yang sekarang sudah menjadi orang-orang hebat mulai dari yang menjadi guru, polisi, DPR, DPRD hingga gubernur. Salah seorang gubernur yang pernah bersekolah disini adalah bapak Razi Yahya seorang mantan gubernur bengkulu yang menjabat pada tahun 1989-1994.

\section{Daftar Pustaka}

Abdurahman, Dudung. Metodologi Penelitian Sejarah, Jogjakarta: AR-RUZZ MEDIA GROUP, 2007.

Ahmad, Fandi.Pemikiran K.H. Ahmad Dahlan Tentang Pendidikan dan Implementasinya di SMP Muhammadiyah 6Yogyakarta Tahun 2014/2015, Jurnal Studi Islam, Vol. 16, No. 2, 2015.

Ali, Mohamad. Membedah Tujuan Pendidikan Muhammadiyah, Jurnal Studi Islam, Vol. 17, No. 1, Surakarta: Juni 2016: 43-56.

Al- Hikmah, Al-Quran dan Terjemahan, Bandung: penerbit Diponegoro, 2004.

Asrohah, Hanun. Sejarah Pendidikan Islam, Jakarta: Logos, 1999.

Daulay, Haidar Putra dan Nurgaya Pasa. PENDIDIKAN ISLAM Dalam Lintas sejarah, Medan: Kencana, 2012.

Darwis, Amri.Metode Penelitian Pendidikan Islam, Jakarta: PT RajaGrafindo Persada, 2014.

Djamas, Nurhayati. Dinamika pendidikan islam di indonesia pascakemerdekaan, jakarta; PT RajaGrafindo Persada, 2008.

Febriana, Leti. Tesis, Dinamika Pendidikan Muhammadiyah dan Kontribusinya terhadap Pendidikan Islam di Bengkulu, Tesis IAIN 
Lety Febriana, Tari Oktaviana, Surohim| Dinamika Pendidikan Dasar Muhammadiyah 151

Bengkulu, 2013.

Hamid, Edy Suandi. Muchlas, dkk. Membangun

Profesionalisme Muhammadiyah, Yogyakar-

ta: LPTP PP Muhammadiyah, 2002

Hasbullah, Dasar-Dasar Ilmu Pendidikan:Edisi

Revisi, Jakarta: PT RajaGrafindo Persada, 2011.

https://id.wikipedia.org/wiki/Kabupaten_Kepahiang, (dowload: 21:51 wib, 15 maret 2018)

https://id.wikipedia.org/wiki/Pendidikan_progresif (dowload 22:20 WIB 1 Juni 2018).

Kholid, Muh. pendidikan Kemuhammadiyahan: untuk SMA/SMK/MA, Surabaya: Majlis Dikdasmen PWM Jatim, 2008

Marlina, leny. "Kajian Terhadap Perkembangan Sekolah Muhammadiyah" jurnal Fakultas Tarbiyah IAIN Raden Fatah Palembang TA'DIB, Vol. XVII, No. 01, Edisi Juni 2012.

Pilli, Salim Bella dan Hardiansyah. Napak Tilas Sejarah Muhammadiyah Bengkulu, Bengkulu: Valia Pustaka, 2016.

Purba, Isma Asmaria Purba dan Ponirin, Perkembangan Amal Usaha Organisasi Muham- madiyah di Bidang Pendidikan dan Kesehatan, Jurnal Ilmu Pemerintahan dan Sosial Politik 1 (2) (2013): 101-111.

Rusyadi, ST Rajjah. "Peran Muhammadiyah (Konsep Pendidikan, Usaha-Usaha Di Bidang Pendidikan, Dan Tokoh)"Jurnal Tarbawi, vol 1, No. 2.

Sugiyono, Metode Penelitian Kombinasi (mixed Methods), Yogyakarta : ALFABETA BANDUNG, 2011.

Sugiyono, Metode Penelitian Pendidikan, Bandung: Alfabeta, 2015.

Surohim, dkk. Pedoman Penulisan Karya Ilmiah \& Skripsi, Fakultas Agama Islam Universitas Muhammadiyah Bengkulu.

Sholihin, Margono Poesposuwarno. beberapa soal jawab ke- Muhammadiyahan, Yogyakarta, 1976.

Tolchah, Moch. Dinamika Pendidikan Islam Pasca Orde Baru, Surabaya: LkiS Pelangi Aksara, 2015.

Zuhairini, dkk. Sejarah Pendidikan Islam, Jakarta : BUMI AKSARA, 2008 